\title{
IMMUNITET PAŃSTWOWEGO STATKU POWIETRZNEGO W ŚWIETLE PRAWA MIĘDZYNARODOWEGO**
}

\section{WPROWADZENIE}

Immunitet państwowego statku powietrznego stanowi interesujące zagadnienie badawcze, które jak dotąd nie zostało w sposób wyraźny uregulowane i stosunkowo rzadko jest omawiane w podstawowych opracowaniach dotyczących prawa międzynarodowego ${ }^{1}$. Kwestia ta może być ściśle związana $\mathrm{z}$ niejednolita praktyką państw w tym zakresie oraz nie w pełni przejrzystymi podstawami prawnymi immunitetu państwowego statku powietrznego. W konsekwencji problematyka ta nie spotkała się z szerszą uwaga doktryny, co potwierdzają zarówno prace Komisji Prawa Międzynarodowego nad immunitetem państwa, jak i niewielka ilość dostępnych opracowań w tym zakresie.

Nieznaczne zainteresowanie immunitetem państwowego statku powietrznego budzi pewne zaskoczenie, jeżeli porównamy je ze stosunkowo dużym znaczeniem, jakie jest przywiązywane do immunitetu państwowych statków morskich. Immunitet państwowych statków morskich jest określony w sposób wyraźny w wielu umowach międzynarodowych ${ }^{2}$. Wynika to z pewnością z długotrwałej, historycznej praktyki wykorzystania statków morskich. Niemniej

* Autor jest pracownikiem Uniwersytetu Kardynała Stefana Wyszyńskiego oraz ekspertem w Departamencie Prawno-Traktatowym MSZ. Wszelkie poglądy wyrażone w niniejszym artykule pochodzą wyłącznie od autora i nie mogą być utożsamiane z stanowiskiem instytucji, w których jest on zatrudniony.

** Autor dziękuje dr. Maciejowi Kałduńskiemu za uwagi dotyczące pierwszej wersji tekstu. Oczywiście wszelkie błędy obciążają wyłącznie autora tekstu.

${ }^{1}$ Brak wzmianki na ten temat w M. N. Shaw, International Law, Cambridge 2009 oraz I. Brownlie, Principles of Public International Law, Oxford 2008; Anthony Aust jedynie powtarza w tym zakresie odesłanie zawarte w Konwencji o immunitecie państw i ich własności z 2004 r. bez żadnego wyjaśnienia, A. Aust, Handbook of International Law, Cambridge 2010, s. 157. Problematyki nie podejmują również polskie podręczniki do prawa międzynarodowego, a nawet opracowania dotyczące immunitetu - zob. M. Menkes, Immunitet jurysdykcyjny i egzekucyjny państwa, Warszawa 2013, s. 59 - w kontekście immunitetu statków powietrznych autor bez wyjaśnienia przywołuje dwie konwencje dotyczące statków morskich z okresu międzywojennego.

${ }^{2}$ Art. 3 Konwencji międzynarodowej o ujednostajnieniu niektórych zasad dotyczących immunitetów statków państwowych z 10 kwietnia 1926 r. oraz art. I Protokołu dodatkowego do tej Konwencji z 24 maja 1934 r. (Dz. U. 1937, Nr 2, poz. 17 oraz Dz. U. 1977, Nr 7, poz. 27); art. 22 ust. 2 Konwencji z 29 kwietnia 1958 r. o morzu terytorialnym i strefie przyległej (https://treaties. un.org/Pages/ParticipationStatus.aspx), Polska nie jest stroną tej Konwencji; art. 8 i 9 Konwencji o morzu pełnym z 29 kwietnia 1958 r. (Dz. U. 1963, Nr 33, poz. 187); art. 32 oraz 236 Konwencji o prawie morza z 10 grudnia 1982 r. (Dz. U. 2002, Nr 59, poz. 543). 
jednak niezwykła intensywność współczesnego międzynarodowego ruchu lotniczego sprawia, że potrzebna jest analiza podstaw prawnych i zakresu obowiązywania również immunitetu państwowych statków powietrznych.

W niniejszym artykule problematyka ta zostanie przedstawiona w pierwszej kolejności w świetle Konwencji Narodów Zjednoczonych o immunitecie państw i ich własności z 2004 r., a następnie na podstawie rozwiązań szczegółowych międzynarodowego prawa lotniczego oraz międzynarodowego prawa morza. Podjęta zostanie również kwestia statusu prawnego oraz zakresu immunitetu państwowego statku powietrznego.

Przedmiotem analizy będzie istnienie, podstawa prawna i zakres immunitetu państwowego statku powietrznego wykorzystywanego w celach niekomercyjnych. Należy bowiem zgodzić się z poglądem, że państwowym statkom powietrznym wykorzystywanym w celach komercyjnych immunitet nie przysługuje ${ }^{3}$.

\section{IMMUNITET PAŃSTWOWEGO STATKU POWIETRZNEGO W KONWENCJI NARODÓW ZJEDNOCZONYCH O IMMUNITECIE PAŃSTWA}

Punktem wyjścia rozważań dotyczących immunitetu statku powietrznego warto uczynić Konwencję Narodów Zjednoczonych (NZ) o immunitecie państw i ich własności z 2 grudnia 2004 r. Konwencja, choć nie weszła jeszcze w życie, powinna być istotnym punktem odniesienia z kilku względów ${ }^{4}$. Po pierwsze, jest jedynym traktatem o charakterze uniwersalnym dotyczacym problematyki immunitetu państwa ${ }^{5}$. Po drugie, Konwencja częściowo kodyfikuje międzynarodowe prawo zwyczajowe w tym zakresie. Po trzecie, mimo że Konwencja jeszcze nie weszła $\mathrm{w}$ życie, to jest przywoływana przez sądy międzynarodowe. Przykładowo na Konwencję wielokrotnie powoływał się, w różnych kontekstach, Międzynarodowy Trybunał Sprawiedliwości w sprawie dotyczącej immunitetu jurysdykcyjnego państwa (sprawa Niemcy przeciwko Włochom) ${ }^{6}$. Trybunał z jednej strony potwierdził, że niektóre rozwiązania konwencyjne znajdują potwierdzenie w praktyce państw (np. podział aktów państwa na iure

\footnotetext{
${ }^{3}$ Second report on jurisdictional immunities of States and their property, by Mr. Motoo Ogiso, Special Rapporteur, A/CN.4/422 \& Corr.1 and Add.1 \& Corr.1, Extract from the Yearbook of the International Law Commission: 1989, vol. II(1), pkt 29.

${ }^{4}$ Według stanu na 2 stycznia 2015 r. stronami Konwencji jest 16 państw. Zgodnie z art. 30 Konwencji wejdzie ona w życie 30. dnia po złożeniu 30. instrumentu ratyfikacji, przystapienia, zatwierdzenia lub przyjęcia Sekretarzowi Generalnego Narodów Zjednoczonych. Konwencja dostępna na: https://treaties.un.org/doc/source/RecentTexts/English_3_13.pdf.

${ }^{5} \mathrm{Na}$ poziomie regionalnym należy odnotować istnienie Europejskiej konwencji o immunitecie państwa z 16 maja 1972 r. (weszła w życie 11 czerwca 1976 r.) oraz Protokołu dodatkowego z 16 maja 1972 r. (wszedł w życie 22 maja 1985 r.). Stronami Konwencji jest 8, a Protokołu - 6 państw. Polska nie związała się tymi traktatami. Konwencja nie odnosi się expressis verbis ani do statków powietrznych, ani do statków morskich.

${ }^{6}$ ICJ Rep. 2012, zob. również Ł. Kułaga, Glosa do wyroku Międzynarodowego Trybunatu Sprawiedliwości $z$ dnia 3 lutego 2012 r. w sprawie immunitetu jurysdykcyjnego państwa (Republika Federalna Niemiec przeciwko Republice Wtoskiej), „Przegląd Sejmowy” 2012, nr 4, s. 214-229.
} 
gestionis oraz iure imperii) $)^{7}$, $\mathrm{z}$ drugiej natomiast wskazywał, że niektóre jej przepisy nie mogą być uznane za odzwierciedlające zwyczaj międzynarodowy (np. art. 12 wyłączajacy immunitet w sprawach cywilnych toczacych się państwie, w którym działanie innego państwa doprowadziło do śmierci, obrażeń lub szkody na mieniu $)^{8}$. Konwencja, jako miarodajny standard stanu prawa międzynarodowego w zakresie immunitetu, była przywoływana wielokrotnie przez Europejski Trybunał Praw Człowieka ${ }^{9}$ oraz przez sądy krajowe ${ }^{10}$.

Konwencja NZ o immunitecie państw i ich własności expressis verbis nie reguluje immunitetu statków powietrznych. Wskazuje jedynie w art. 3 ust. 3, że:

Niniejsza Konwencja jest bez uszczerbku dla immunitetów, z których korzysta państwo na podstawie prawa międzynarodowego w odniesieniu do samolotów lub obiektów kosmicznych, które są własnością państwa lub są przez nie wykorzystywane.

Odmiennie natomiast Konwencja traktuje problematykę państwowych statków morskich, w zakresie których jej art. 16 uznaje istnienie immunitetu takiego statku, jeżeli jest on wykorzystywany do rządowych celów o charakterze niekomercyjnym ${ }^{11}$. To rozróżnienie Hazel Fox tłumaczy faktem niejednoli-

${ }^{7}$ Ibidem, $\S 61$.

${ }^{8}$ Ibidem, $\S 64$.

${ }_{9}$ Zob. np. Cudak przeciwko Litwie, skarga nr 15869/02, wyrok z 23 marca 2010 r., w $§ 67$ wyroku Trybunał prezentuje pogląd nt. zwyczajowego charakteru postanowień Konwencji; Oleynikov przeciwko Rosji, skarga nr 36703/04, wyrok z 14 marca 2013 r. Na temat zwyczajowego charakteru postanowień Konwencji zob. § 61 oraz 66; Wallishauser przeciwko Austrii, skarga nr 14497/06, wyrok z 20 czerwca 2013 r., w $§ 29$ i 71 wyroku wskazuje się, że Konwencja kodyfikuje międzynarodowe prawo zwyczajowe dotyczące immunitetu państwa. Krytycznie nt. podejścia Europejskiego Trybunału Praw Człowieka do zwyczaju międzynarodowego w kontekście Konwencji Narodów Zjednoczonych zob. M. Kałduński, M. Balcerzak, Immunitet jurysdykcyjny państwaglosa do wyroku ETPCz z 23.03.2010 r. w sprawie Cudak v. Litwa, „Europejski Przegląd Sądowy” 2010, nr 11, s. 40-44.

${ }_{10}$ Zob. np. Jones i inni przeciwko Arabii Saudyjskiej, wyrok Izby Lordów z 14 czerwca 2006 r., http://www.interights.org/document/101/index.html, § 8 i 47; postanowienie SN z 29 października 2010 r., IV CSK 465/09, http://wpia2.uni.lodz.pl/zeupi/pliki_upload/IV\%20CSK\%20465\%20\%20 $\% 2009 \% 20$ Natoniewski\%20wyrok.pdf, s. 5.

11 „1. Unless otherwise agreed between the States concerned, a State which owns or operates a ship cannot invoke immunity from jurisdiction before a court of another State which is otherwise competent in a proceeding which relates to the operation of that ship if, at the time the cause of action arose, the ship was used for other than government non-commercial purposes. 2. Paragraph 1 does not apply to warships, or naval auxiliaries, nor does it apply to other vessels owned or operated by a State and used, for the time being, only on government non-commercial service. 3. Unless otherwise agreed between the States concerned, a State cannot invoke immunity from jurisdiction before a court of another State which is otherwise competent in a proceeding which relates to the carriage of cargo on board a ship owned or operated by that State if, at the time the cause of action arose, the ship was used for other than government non-commercial purposes. 4 . Paragraph 3 does not apply to any cargo carried on board the ships referred to in paragraph 2, nor does it apply to any cargo owned by a State and used or intended for use exclusively for government non-commercial purposes. 5. States may plead all measures of defence, prescription and limitation of liability which are available to private ships and cargoes and their owners. 6 . If in a proceeding there arises a question relating to the government and non-commercial character of a ship owned or operated by a State or cargo owned by a State, a certificate signed by a diplomatic representative or other competent authority of that State and communicated to the court shall serve as evidence of the character of that ship or cargo". 
tego traktowania rządowych samolotów w konwencjach międzynarodowych ${ }^{12}$. Natomiast Roger O’Keefe prezentuje pogląd, że „Konsekwencją art. 3 ust. 3 [...] jest tylko tyle, że w przypadku sprzeczności pomiędzy Konwencją a jakąkolwiek inną normą prawa międzynarodowego obowiązującą pomiędzy państwem obcym i państwem forum, dotyczacca immunitetu jurysdykcyjnego oraz egzekucyjnego [...], ta inna norma ma pierwszeństwo. W braku takiej normy prawa międzynarodowego [...] art. 3 ust. 3 nie wywołuje żadnego skutku i Konwencja znajduje zastosowanie"13.

Konwencja NZ o immunitecie państw i ich własności została oparta na projekcie przygotowanym przez Komisję Prawa Międzynarodowego w 1991 r. (dalej jako: Komisja lub KPM) ${ }^{14}$. Dlatego poszukując ram prawnych dotyczących immunitetu państwowych statków powietrznych, warto odnieść się do prac Komisji. W pierwszej kolejności należy odnotować, że projekt KPM również nie odwoływał się do statku powietrznych, przy czym nie zawierał on nawet odsyłajacego postanowienia z art. 3 ust. 3 Konwencji. Stosunkowo lakonicznie do problematyki państwowych statków powietrznych KPM odniosła się w komentarzu do projektu artykułów. Wskazuje się w nim, że istnieje pewna praktyka dotyczacca immunitetu statków powietrznych ${ }^{15}$, oraz na niemożność zastosowania art. 16 dotyczącego statków morskich, który następnie został przeniesiony do Konwencji, do statków powietrznych. Komisja wydaje się równocześnie podpowiadać w przypisie do komentarza do art. 16, że ta problematyka powinna być rozstrzygnięta na podstawie traktatów dotyczących lotnictwa cywilnego ${ }^{16}$.

Drugi Specjalny Sprawozdawca Komisji Prawa Międzynarodowego w zakresie immunitetu państw i ich własności Motoo Ogiso w swoim drugim raporcie prezentował pogląd, że „nie istnieje jednolita norma międzynarodowego prawa zwyczajowego dotycząca immunitetu samolotów, których właścicielem lub operatorem jest państwo"17. Równocześnie z powodu niewielkiej praktyki państw w tym zakresie nie zdecydował się on na przedstawienie odrębnego postanowienia dotyczącego immunitetu państwowych statków powietrznych w projekcie artykułów ${ }^{18}$. Postulat wprowadzenia do projektu artykułów postanowienia dotyczącego statków powietrznych jedynie w niewielkim stopniu był podnoszony w stanowiskach państw odnoszacych się do prac KPM ${ }^{19}$.

12 H. Fox, The Law of State Immunity, Oxford 2008, s. 181.

${ }^{13}$ R. O'Keefe, Article 3, w: idem, Ch. J. Tams, A. Tzanakopoulos (eds.), The United Nations Convention on Jurisdictional Immunities of States and Their Property: A Commentary, Oxford 2013, s. 91 (tłum. własne).

${ }^{14}$ Draft Articles on Jurisdictional Immunities of States and Their Property 1991, „Yearbook of the International Law Commission” 1991, vol. 2 (Part Two).

${ }_{15}$ Niemniej przywołana jest tylko jedna sprawa - Hong Kong Aircraft-Civil Air Transport Inc. v. Central Air Transport Corp. (1953), ibidem, s. 25.

16 Ibidem, s. 53-54.

17 Second report..., pkt 31 (tłum. własne).

18 Ibidem. Podobny pogląd wyrażało wielu członków Komisji, zob. Report of the International Law Commission on the work of its forty-first session, 2 May - 21 July 1989, Official Records of the General Assembly, Forty-fourth Session, Supplement No. 10, Extract from the Yearbook of the International Law Commission 1989, vol. II(2)A/44/10, pkt 552.

${ }_{19}$ Tak np. Szwajcaria, A/CN.4/410 and Add.1-5 Comments and observations received from Governments Extract from the Yearbook of the International Law Commission 1988, vol. II(1), s. 95. 
Komitet Redakcyjny Komisji odnotował, że problematyka jest skomplikowana i może wymagać sformułowania dodatkowych definicji takich pojęć, jak samolot prezydencki, samoloty cywilne wykorzystywane przez władze państwowe do operacji ratunkowych czy samoloty wykorzystywane w misjach dyplomatycznych ${ }^{20}$. Przewodniczacy tego komitetu Stanisław Pawlak informował, że: „Komitet redakcyjny niemniej uznał, że kwestia ta jest aktualna, i był świadomy, że brak postanowień dotyczacych samolotów w projekcie może być postrzegany jako luka [...]. Z tego względu zwrócił uwagę Komisji na kwestię statusu z perspektywy immunitetu statków powietrznych i obiektów wypuszczonych w przestrzeń kosmiczną"21.

Ostatecznie wprowadzenie do projektu Konwencji cytowanego już art. 3 ust. 3 nastapiło w trakcie prac Komitetu Ad Hoc, który w 2002 r. odnotował, że brak odniesienia się w projekcie przygotowanym przez KPM do immunitetu państwowych statków powietrznych oraz obiektów kosmicznych stanowi lukę $^{22}$. W tym kontekście trafny jednak wydaje się pogląd, że klauzula z art. 3 ust. 3 Konwencji w niewielkim stopniu tę lukę wypełnia.

\section{MIĘDZYNARODOWE PRAWO LOTNICZE A IMMUNITET PAŃSTWOWEGO STATKU POWIETRZNEGO}

Kontrowersje w pracach KPM dotyczace stwierdzenia obowiazywania immunitetu państwowych statków powietrznych wiązały się z faktem, że jednoznacznej odpowiedzi w tym zakresie nie udzielaja traktaty z zakresu międzynarodowego prawa lotniczego. Niemniej rekonstrukcja niektórych postanowień tych umów pozwala na sformułowanie pewnych wniosków w tym zakresie.

Konwencja dotyczaca regulacji nawigacji lotniczej podpisana w Paryżu 13 października 1919 r. w art. 32 określa, że w przypadku zgody na przelot samolotu wojskowego przez przestrzeń powietrzną obcego państwa „korzysta on, co do zasady i w braku szczególnych regulacji z przywilejów, które zwyczajowo sa przyznane obcym statkom wojennym" ${ }^{23}$. Konwencja o międzynarodowym lotnictwie cywilnym, podpisana w Chicago 7 grudnia 1944 r. w art. 3 pkt b definiuje państwowe statki powietrzne jako ,statki powietrzne używane w służbie wojskowej, celnej i policyjnej" ${ }^{24}$, niemniej wyliczenie to nie jest uznawane za wyczerpujące ${ }^{25}$. Równocześnie Konwencja nie zawiera żadnych postano-

${ }^{20}$ Draft Articles on Jurisdictional Immunities..., pkt 83.

21 Ibidem (tłum. własne).

${ }^{22}$ Report of the Ad Hoc Committee on Jurisdictional Immunities of States and Their Property, 4-15 February 2002, General Assembly Official Records Fifty-seventh Session, Supplement No. 22 (A/57/22), s. 9.

${ }^{23}$ Konwencja dostępna na: http://www.spacelaw.olemiss.edu/library/aviation/IntAgr/multilateral/1919_Paris_conevention.pdf. Polska nie jest stroną tej Konwencji.

${ }_{24}$ Dz. U. 1959, Nr 35, poz. 212 ze zm.

${ }_{25}$ M. Żylicz, Katastrofa smoleńska w świetle międzynarodowego prawa lotniczego, „Państwo i Prawo" 66, 2011, z. 4, s. 5 i cytowana tam literatura. 
wień dotyczących immunitetu tych statków ${ }^{26}$. Przekonujący wydaje się jednak pogląd Johna C. Cooopera, przewodniczącego komitetu przygotowującego art. 3, że: „norma określona w Konwencji paryskiej zakładająca, że samolotowi $\mathrm{w}$ służbie wojskowej należy $\mathrm{w}$ braku przeciwnej regulacji przyznać przywileje statków wojskowych [...], może być nadal uznawana za część międzynarodowego prawa lotniczego, mimo że nie została potwierdzona w Konwencji chicagowskiej”27.

Wskazówki sugerujące, że państwowym statkom powietrznym może przysługiwać immunitet, można odnaleźć w niektórych innych traktatach z zakresu międzynarodowego prawa lotniczego. Artykuł 3 ust. 1 pkt a Konwencji o ujednostajnieniu niektórych prawideł dotyczacych zajęcia zabezpieczającego statków powietrznych z 29 maja 1933 r. określa, że: „Nie podlegają zajęciu zabezpieczającemu a) statki powietrzne przeznaczone wyłącznie do służby państwowej, włącznie z poczta, a z wyłączeniem obrotu handlowego" ${ }^{28}$. Konwencja dotycząca szkód wyrządzonych osobom trzecim na powierzchni ziemi przez obce statki powietrzne z 7 października $1952 \mathrm{r}$. zezwala na wszczynanie postępowań cywilnych również w przypadku wypadków samolotów będących własnościa państwa, niemniej w art. 26 wyraźnie określa, że nie ma zastosowania do szkody spowodowanej przez samoloty wojskowe, celne lub policyjne ${ }^{29}$. Podobnie Konwencja dotycząca odszkodowań za szkody wyrządzone przez statki powietrzne osobom trzecim z 2 maja 2009 r. w art. 2 ust. 4 stanowi, że „nie ma zastosowania do szkód wyrządzonych przez samoloty państwowe. Samoloty używane w służbie wojskowej, celnej i policyjnej należy uznawać za samoloty państwowe"30.

Klauzule wyłączające możliwość stosowania konwencji do samolotów państwowych zostały zawarte również we wszystkich traktatach dotyczących zwalczania przestępczości przeciwko bezpieczeństwu transportu lotniczego ${ }^{31}$.

${ }^{26}$ Podobnie brak postanowień w tym zakresie w Konwencji o ujednostajnieniu niektórych prawideł dotyczacych międzynarodowego przewozu lotniczego z 12 października $1929 \mathrm{r}$. (Dz. U. 1933, Nr 8, poz. 49).

${ }^{27}$ I. A. Vlasic (ed.), Explorations in Aerospace Law: Selected Essays by John Cobb Cooper, 1946-1966, Montreal 1968, s. 243, za: A. S. Williams, The interception of civil aircraft over the high seas in the global war on terror, „Air Force Law Review” 59, 2007, s. 105 (tłum. własne).

${ }^{28}$ Dz. U. R. P. 1937, Nr 33, poz. 254.

${ }^{29}$ Konwencja dostępna na: http://cil.nus.edu.sg/1952/1952-convention-on-damage-caused-by-foreign-aircraft-to-third-parties-on-the-surface/. Polska nie jest stroną Konwencji.

${ }^{30}$ Konwencjadostępnana:www.ulc.gov.pl/_download/prawo/prawo_miedzynarodowe/konwencje 19919_g.pdf. Polska nie jest stroną Konwencji.

${ }^{31}$ Art. 1 ust. 4 Konwencji w sprawie przestępstw i niektórych innych czynów popełnionych na pokładzie statków powietrznych z 14 września 1963 r. (Dz. U. 1971, Nr 15, poz. 147); art. 3 ust. 2 Konwencji o zwalczaniu bezprawnego zawładnięcia statkami powietrznymi z 16 grudnia 1970 r. (Dz. U. 1972, Nr 25, poz. 181); art. 4 ust. 1 Konwencji o zwalczaniu bezprawnych czynów skierowanych przeciwko bezpieczeństwu lotnictwa cywilnego z 23 września 1971 r. (Dz. U. 1976, Nr 8, poz. 37); art. 5 ust. 1 Konwencji o zwalczaniu bezprawnych aktów dotyczących międzynarodowego lotnictwa cywilnego z 10 września 2010 r. - nie weszła jeszcze w życie. Polska nie jest jej strona. 
Podsumowując, niektóre konwencje z zakresu międzynarodowego prawa lotniczego zawierają postanowienia sugerujące szczególny charakter państwowych statków powietrznych niewykorzystywanych do celów komercyjnych, polegający na wyłączeniu jurysdykcji organów obcego państwa. Równocześnie traktaty te nie wskazują explicite, że statkom tym przysługuje immunitet.

\section{KONWENCJE DOTYCZĄCE PRAWA MORZA A IMMUNITET PAŃSTWOWEGO STATKU POWIETRZNEGO}

Julian Sutor prezentuje pogląd, że „status państwowych statków powietrznych, zwłaszcza samolotów wojskowych, jest na podstawie międzynarodowego prawa zwyczajowego, faktycznie analogiczny do statusu prawnego okrętów wojennych i innych państwowych jednostek pływających nie wykorzystywanych do celów handlowych"32. Jako główny argument przemawiajacy za taka tezą autor wskazuje na regulacje zawarte w Konwencji o prawie morza z 1982 r. $^{33}$

Postanowienia Konwencji o prawie morza rzeczywiście mają wyjątkowe znaczenie z perspektywy oceny obowiązywania immunitetu państwowego samolotu powietrznego z tego względu, że niekiedy zrównują go z immunitetem statków morskich. Niemniej jednak zrównanie to ma charakter jedynie szczątkowy. W art. 42 ust. 5 Konwencji odnoszącym się do ustaw i innych przepisów prawnych państw położonych nad cieśninami, dotyczących przejścia tranzytowego $^{34}$ oraz w art. 236 Konwencji dotyczacym ochrony i zachowania środowiska morskiego ${ }^{35}$ wskazuje się na tożsamość immunitetu państwowych statków powietrznych i morskich.

32 J. Sutor, Immunitet państwa, Warszawa 2011, s. 211.

33 Dz. U. 2002, Nr 59 poz. 543.

34 „3. Państwa położone nad cieśninami podają w należyty sposób do publicznej wiadomości informację o wszelkich takich ustawach i innych przepisach. 4. Obce statki morskie korzystające z prawa przejścia tranzytowego przestrzegają takich ustaw i innych przepisów. 5. Jeżeli statek morski lub statek powietrzny korzystający z immunitetu przysługującego obcemu państwu postępuje w sposób sprzeczny z takimi ustawami i innymi przepisami albo innymi postanowieniami niniejszej części, to państwo bandery statku morskiego lub państwo rejestracji statku powietrznego ponosi międzynarodową odpowiedzialność za wszelkie straty lub szkody wyrządzone państwom położonym nad cieśninami”.

${ }^{35}$ „Artykuł 236 Immunitet wynikający z suwerenności. Postanowienia niniejszej konwencji dotyczące ochrony i zachowania środowiska morskiego nie mają zastosowania do okrętów wojennych, pomocniczych okrętów marynarki wojennej, innych statków morskich i powietrznych będących własnością państwa lub eksploatowanych przez państwo i używanych w danym czasie wyłącznie w rządowej służbie niehandlowej”. Do przedmiotowego przepisu w zakresie immunitetu samolotów Bangladesz i Malta złożyły identycznej treści deklarację, przystępując do Konwencji o prawie morza, o następującej treści: „the sovereign immunity as envisaged in article 236 does not relieve a State from the obligation, moral or otherwise, in accepting responsibility and liability for compensation and relief in respect of damage caused by pollution of the marine environment by any warship, naval auxiliary, other vessels or aircraft owned or operated by the State and used on government non-commercial service". 
Równocześnie jednak w Konwencji zawarto postanowienia, które przewidują immunitety wyłącznie dla statków morskich, milcząc na temat statków powietrznych. Takie sformułowanie znaleźć można w odniesieniu do statków morskich na morzu terytorialnym (art. 32) oraz na morzu otwartym (art. 95 i 96). Brak w Konwencji normy dotyczącej immunitetu państwowych statków powietrznych znajdujacych się nad morzem otwartym jest szczególnie dostrzegalny w świetle faktu, że traktat ten przewiduje równocześnie wolność przelotu nad tym obszarem (art. 87).

W kontekście obowiązywania reżimu Konwencji o prawie morza warto odnotować rozstrzygnięcie funkcjonującego na jej podstawie Międzynarodowego Trybunału Prawa Morza, dotyczące immunitetu statków państwowych. W zarządzeniu o środkach tymczasowych z 15 grudnia $2012 \mathrm{r}$. w sprawie statku „ARA Libertad” (Argentyna przeciwko Ghanie), Trybunał wskazał, że statki wojenne stanowia wyraz suwerenności państwa ich bandery, a zgodnie z powszechnym prawem międzynarodowym korzystaja z immunitetu (§ 94-95). Zauważył również, że „działania podjęte przez władze Ghany, które uniemożliwiają "ARA Libertad" statkowi wojennemu należącemu do argentyńskiej marynarki wojennej wypełnianie jego zadań oraz obowiązḱw, naruszaja immunitet, z jakiego korzysta ten statek wojenny na podstawie powszechnego prawa międzynarodowego" (§ 98 $)^{36}$. Znaczące jest, że Międzynarodowy Trybunał Prawa Morza wskazywał na istnienie immunitetu morskich statków wojennych na podstawie powszechnego prawa międzynarodowego, a nie tylko na podstawie samej Konwencji o prawie morza. Z dużym prawdopodobieństwem można przyjaćc, że podobne uprawnienia przysługują wojennym statkom powietrznym ${ }^{37}$.

Pogląd o podobnym charakterze immunitetów statków powietrznych i morskich został sformułowany również w Konwencji o ochronie podwodnego dziedzictwa kulturowego z 6 listopada $2001 \mathrm{r}^{38} \mathrm{~W}$ art. 13 Konwencji mówi się o ,statkach wojennych i innych rządowych statkach oraz samolotach wojskowych korzystających z suwerennego immunitetu (ang. with sovereign immunity) działających w celach niekomercyjnych". Równocześnie jednak w art. 2 ust. 8 tego traktatu zastrzega się, że „Zgodnie z praktyka państw i prawem międzynarodowym, w tym Konwencją o prawie morza, niniejsza Konwencja nie będzie interpretowana jako zmieniająca normy prawa międzynarodowego

${ }^{36}$ Zarządzenie dostępne na stronie Trybunału: https://www.itlos.org/fileadmin/itlos/documents/cases/case_no.20/C20_Order_15.12.2012.corr.pdf (tłum. własne).

${ }^{37}$ Podobnie A. S. Williams, op. cit., s. 105; C. Allen, Law of the Sea Tribunal Resoundingly Affirms the Sovereign Immunity of Warships and Orders Ghana to Release Argentine Tall Ship ARA Libertad, December 15th, 2012, http://opiniojuris.org/2012/12/15/.

${ }_{38}$ Tłum. własne. Konwencja dostępna na: http://portal.unesco.org/en/ev.php-URL_ID=13520\& URL_DO=DO_TOPIC\&URL_SECTION=201.html, weszła w życie 2 stycznia 2009 r. Polska nie jest strona Konwencji. Szerzej nt. Konwencji zob. J. Symonides, Międzynarodowa ochrona podwodnego dziedzictwa kulturowego, ,Stosunki Międzynarodowe” 2003, nr 1-2, s. 51-62. Warto odnotować problem z określeniem daty ustalenia autentyczności tekstu przedmiotowej Konwencji. W jej treści wskazuje się na 6 listopada 2001 r., niemniej depozytariusz, którym jest UNESCO, określa, że Konwencja jest z 2 listopada 2001 r., co wydaje się jednak nietrafne, ponieważ ta ostatnia data była najprawdopodobniej jedynie datą przyjęcia tekstu. 
oraz praktykę państw dotyczącą suwerennych immunitetów, lub jakichkolwiek praw w odniesieniu do ich statków morskich i powietrznych".

Przedstawiona praktyka traktatowa pokazuje, że paradoksalnie expressis verbis statkom powietrznym immunitet jest przyznawany raczej w konwencjach z zakresu prawa morza, aniżeli prawa lotniczego. Ich znaczenie jest o tyle szczególne, że są to jedynie wielostronne umowy międzynarodowe odnoszące się do tej problematyki. Równocześnie jednak niejasne jest, dlaczego Konwencja o prawie morza tylko w niektórych przepisach zestawia immunitet państwowego statku powietrznego ze statkiem morskim, a w innych, w szczególności tych dotyczący morza otwartego, brak takiego odniesienia.

\section{STATUS PRAWNY IMMUNITETU PAŃSTWOWEGO STATKU POWIETRZNEGO}

Jak już przedstawiono, immunitet państwowych statków powietrznych może być wywodzony explicite z Konwencji o prawie morza oraz implicite z niektórych traktatów z zakresu międzynarodowego prawa lotniczego. Równocześnie państwowy statek powietrzny może być objęty immunitetem na podstawie traktatów dotyczących stosunków dyplomatycznych w sytuacji, gdy stanowi środek transportu osób lub mienia chronionego na podstawie tych umów. W szczególności zastosowanie moga znaleźć w tym zakresie Konwencja wiedeńska o stosunkach dyplomatycznych z 18 kwietnia $1961 \mathrm{r} .^{39}$, Konwencja wiedeńska o stosunkach konsularnych z 24 kwietnia 1963 r. ${ }^{40}$ oraz Konwencja o misjach specjalnych z 16 grudnia 1969 r. $^{41}$

Pewne kontrowersje wzbudza kwestia zwyczajowego charakteru immunitetu państwowych statków powietrznych. Wiąże się to przede wszystkim z brakiem uregulowania tego immunitetu w pracach KPM i w konsekwencji również w Konwencji NZ z 2004 r. Pewnym odzwierciedleniem tego stanowiska jest cytowany już pogląd, że „nie istnieje jednolita norma międzynarodowego prawa zwyczajowego dotycząca statków powietrznych, których właścicielem jest państwo lub które są eksploatowane przez państwo”, przedstawiony w 1989 r. przez drugiego specjalnego sprawozdawcę KPM w zakresie

\footnotetext{
${ }^{39}$ Przykładowo art. 22 ust. 3 Konwencji stanowi, że „Pomieszczenia misji, ich urządzenia i inne przedmioty, które się w nich znajduja, oraz środki transportu misji nie podlegają rewizji, rekwizycji, zajęciu lub egzekucji”, Dz. U. 1965, Nr 37, poz. 232.

40 Przykładowo art. 31 ust. 4 Konwencji stanowi, że: „Pomieszczenia konsularne, ich urządzenia, mienie urzędu konsularnego, jak również jego środki transportu nie podlegają żadnej postaci rekwizycji na cele obrony narodowej lub użyteczności publicznej. Jeżeli na te cele niezbędne jest wywłaszczenie, powinny być przedsięwzięte wszelkie odpowiednie środki dla uniknięcia utrudnienia wykonywania funkcji konsularnych i powinno być niezwłocznie wypłacone państwu wysyłającemu odpowiednie i efektywne odszkodowanie”, Dz. U. 1982, Nr 13, poz. 98.

${ }^{41}$ Przykładowo art. 25 ust. 3 Konwencji stanowi, że „Pomieszczenia misji specjalnej, ich umeblowanie, inne przedmioty służące do funkcjonowania misji specjalnej oraz jej środki transportu nie mogą być przedmiotem jakiejkolwiek rewizji, rekwizycji, zajęcia albo egzekucji”, Dz. U. 1985, Nr 48, poz. 245.
} 
immunitetu państw i ich własności ${ }^{42}$. Z tą tezą nie zgadzali się jednak wszyscy członkowie Komisji ${ }^{43}$.

Pogląd o zwyczajowym charakterze immunitetu państwowych statków powietrznych prezentuja Austria ${ }^{44}$, Finlandia ${ }^{45}$, Irlandia ${ }^{46}$ oraz Stany Zjednoczone $^{47}$. Równocześnie warto odnotować, że istniejace krajowe akty prawne dotyczące immunitetu państwa nie reguluja problematyki immunitetu państwowego statku powietrznego ${ }^{48}$.

Bez rozstrzygania definitywnie kwestii, czy istnieje powszechna, jednolita i spójna praktyka państw w zakresie przyznawania immunitetu państwowym statkom powietrznym, warto wskazać, że immunitet ten może być powoływany jako konsekwencja obowiazywania w prawie międzynarodowym zasady suwerennej równości państw. Pogląd ten znalazł potwierdzenie w wspomnianym już wyroku w sprawie immunitetów jurysdykcyjnych, w którym Międzynarodowy Trybunał Sprawiedliwości stwierdził, że „norma dotycząca immunitetu państwa zajmuje istotne miejsce w prawie międzynarodowym i w stosunkach międzynarodowych. Wynika ona z zasady suwerennej równości państwa, która zgodnie z art. 2 ust. 2 Karty Narodów Zjednoczonych, jest jedną z fundamentalnych zasad międzynarodowego porządku prawnego" ${ }^{49}$.

${ }^{42}$ Second report..., pkt 31 (tłum. własne).

${ }^{43} \mathrm{~W}$ trakcie dyskusji odmienny pogląd zaprezentował np. S. C. McCaffrey, Summary record of the 2120th meeting, A/CN.4/SR.2120, Extract from the Yearbook of the International Law Commission 1989, vol. I, pkt 57.

${ }^{44}$ Odpowiednie przepisy dotyczące samolotów państwowych wykorzystywanych w lotach obserwacyjnych na podstawie Traktatu o otwartych przestworzach, zob. szerzej stanowisko przedłożone do bazy informacji nt. immunitetu państwa Rady Europy, http://www.coe.int/t/dlapil/cahdi/ Source/state_immunities/Cahdi\%20\%282005\%29\%206\%20bil\%20PartI\%20Austria.pdf, s. 9.

${ }^{45} \mathrm{~W}$ kontekście samolotów wojskowych Finlandia prezentuje pogląd, że: „The leading principle has been that property which relates to acts of government enjoys immunity as an expression of the sovereignty of the flag state", zob. szerzej stanowisko przedłożone do bazy informacji nt. immunitetu państwa Rady Europy, http://www.coe.int/t/dlapil/cahdi/Source/state_immunities/CAHDI\%20_2005_\%206\%20bil\%20Part\%20I\%20FINLAND.pdf, s. 26 [dostęp: 30.11.2015].

${ }^{46}$ Zob. odpowiedź irlandzkiego Ministra ds. Sprawiedliwości i Równości na pytanie deputowanych w sprawie lądowań państwowych samolotów obcych państw na irlandzkim lotnisku Shannon, dostępne na: http://oireachtasdebates.oireachtas.ie/debates\%20authoring/debateswebpack. nsf/takes/dail2013121000070.

${ }^{47}$ Takie stanowisko Stany Zjednoczone zaprezentowały w sporze z ChRL dotyczacym awaryjnego lądowania amerykańskiego samolotu zwiadowczego na chińskiej wyspie Hainan w kwietniu 2001 r., Digest of United States Practice in International Law 2001, Washington 2002, s. 709; zob. również F. L. Kirgis, United States Reconnaisance Aircraft Collision with Chinese Jet, „ASIL Insights" 6, 2001, issue 7, http://www.asil.org/insights.

${ }^{48}$ Zob. np. brytyjski State Immunity Act (zawierający odesłanie tylko do statków morskich), dostępne na: http://www.legislation.gov.uk/ukpga/1978/33; amerykański Foreign Sovereign Immunities Act, 28 U.S. Code Chapter 97, § 1602-1611; australijski Foreign States Immunities Act 1985 (zawierający odesłanie tylko do statków morskich), dostępny na: http://www.comlaw.gov. au/Details/C2010C00145; kanadyjski State Immunity Act 1985 (zawierający odesłanie tylko do statków morskich), dostępny na: http://www.coe.int/t/dlapil/cahdi/Source/state_immunities/CANADA_Immunities_2013_State_Immunity_Act.pdf.; izraelski Foreign State Immunity Act 57692008 (zawierający odesłanie tylko do statków morskich), dostępny na: http://www.coe.int/t/dlapil/ cahdi/Source/state_immunities/Israel\%20Immunities\%20January\%202009.pdf.

${ }^{49}$ ICJ Rep. 2012, § 57 (tłum. własne), zob. również M. Kaldunski, The law of state immunity in the case concerning jurisdictional immunities of the state (Germany $v$. Italy), „The Law and Practice of International Courts and Tribunals" 13, 2014, s. 64-69. 


\section{ZAKRES IMMUNITETU}

Immunitet państwowego statku powietrznego ma charakter w pierwszej kolejności jurysdykcyjny, zatem dotyczy immunitetu od postępowania przed organami sprawiedliwości innego państwa i dotyczy problematyki uregulowanej w części II i III Konwencji NZ o immunitecie państwa ${ }^{50}$. W szczególności art. 6 Konwencji, który można uznać za odzwierciedlający normy zwyczajowe, wskazuje, że państwo powinna zapewnić skuteczność immunitetowi przez powstrzymanie się od wykonywania swojej jurysdykcji w postępowaniu przed sądami krajowymi przeciwko innemu państwu. Dodatkowo art. 18 i 19 Konwencji wskazuja, że nie mogą być stosowane żadne środki ograniczające możliwość wykorzystania własności państwowej.

\section{PODSUMOWANIE}

Rekonstrukcja istnienia immunitetu państwowego statku powietrznego wykorzystywanego do celów niekomercyjnych nie należy do kwestii łatwych. Może to budzić zdumienie, biorąc pod uwagę, po pierwsze, długoletnie prace Komisji Prawa Międzynarodowego w zakresie immunitetu państwa oraz przyjęcie wielostronnej konwencji międzynarodowej w tym zakresie na forum NZ, a po drugie, rozbudowany reżim prawny dotyczący immunitetu państwowych statków morskich. Wiąże się to z faktem stosunkowo niewielkiej praktyki państw w zakresie immunitetu statków powietrznych oraz fragmentarycznej regulacji tej problematyki w umowach międzynarodowych. Rezultatem przedstawionego w artykule procesu badawczego jest teza, że państwowemu statkowi powietrznemu wykorzystywanemu do celów niekomercyjnych przysługuje immunitet na podstawie niektórych konwencji wielostronnych. Co ciekawe, kluczowe znaczenie w tym zakresie mają traktaty dotyczace prawa morza, a nie prawa lotniczego. Ponadto zasadne jest również twierdzenie, że immunitet ten wynika z powszechnego prawa międzynarodowego, aczkolwiek ze względu na pewne kontrowersje, co do istnienia wystarczającej praktyki państw oraz opinio iuris w zakresie państwowych statków powietrznych, posiłkowo można dowodzić, że immunitet ten jest elementem immunitetu państwa per se oraz konsekwencją obowiązywania zasady suwerennej równości państw w prawie międzynarodowym.

\section{dr Łukasz Kułaga}

Uniwersytet Kardynała Stefana Wyszyńskiego w Warszawie

l.kulaga@uksw.edu.pl

\footnotetext{
${ }^{50}$ R. O’Keefe, op. cit., s. 91.
} 


\section{IMMUNITY OF A STATE AIRCRAFT IN LIGHT OF INTERNATIONAL LAW}

\section{Sum mary}

The immunity of a state aircraft is an interesting research area, but rarely addressed in international law or discussed in the doctrine of international law. Little interest in this regard is surprising if we compare it with the relatively broadly discussed issue of immunity of state vessels.

The result of the research process presented in the article is the thesis that an aircraft owned or operated by a State for non-commercial purposes is entitled to immunity under certain multilateral conventions. Interestingly, crucial in this respect are treatises related to the law of the sea, rather than air law. It is also justifiable to claim that the discussed immunity arises from general international law. 